\title{
Enantioselective Recognition of Carboxylates: A Receptor Derived from $\alpha$-Aminoxy Acids Functions as a Chiral Shift Reagent for Carboxylic Acids
}

\author{
Dan Yang*\$๋, Xiang Li ${ }^{\dagger}$, Yun-Fei Fan ${ }^{\S}$, and Dan-Wei Zhang ${ }^{\S}$ \\ ${ }^{\S}$ Department of Chemistry, Fudan University, Shanghai, China, \\ 'Department of Chemistry, The University of Hong Kong, Pokfulam Road, \\ Hong Kong, China
}

\section{Supporting Information}

Synthesis of receptor 1:
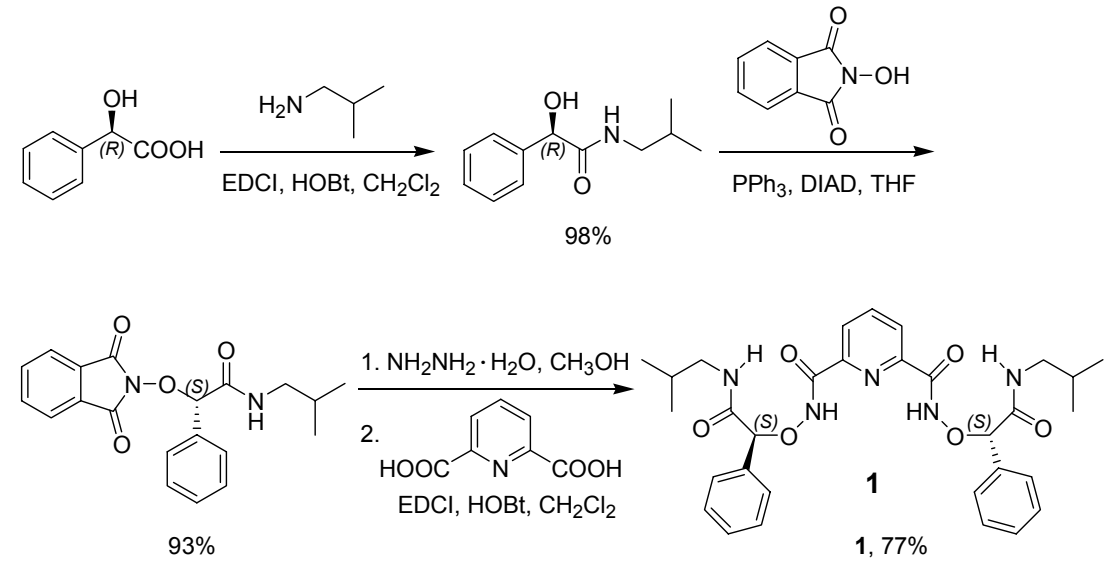

\section{Characterization data for compound 1 :}

White solid; mp 202-204 ${ }^{\circ} \mathrm{C} ;[\alpha]^{20}{ }_{\mathrm{D}}-77.0^{\circ}$ (c 1.00, $\left.\mathrm{CHCl}_{3}\right) ;{ }^{1} \mathrm{H}$ NMR $\left(400 \mathrm{MHz}, \mathrm{CDCl}_{3}\right.$ ) $\delta 11.64(\mathrm{~s}, 2 \mathrm{H}), 8.20(\mathrm{~d}, J=7.8 \mathrm{~Hz}, 2 \mathrm{H}), 8.16(\mathrm{t}, J=5.9 \mathrm{~Hz}, 2 \mathrm{H}), 7.98(\mathrm{t}, J=7.8 \mathrm{~Hz}, 1 \mathrm{H})$, 7.36-7.34 (m, 4H), 7.21-7.18 (m, 6H), $5.25(\mathrm{~s}, 2 \mathrm{H}), 3.09-3.05(\mathrm{~m}, 4 \mathrm{H}), 1.79-1.75(\mathrm{~m}, 2 \mathrm{H}), 0.85$ $(\mathrm{d}, J=6.4 \mathrm{~Hz}, 6 \mathrm{H}), 0.83(\mathrm{~d}, J=6.4 \mathrm{~Hz}, 6 \mathrm{H}) ;{ }^{13} \mathrm{C} \mathrm{NMR}\left(75 \mathrm{MHz}, \mathrm{CDCl}_{3}\right) \delta 170.11,162.66$, $147.45,139.27,134.99,129.19,128.67,127.75,125.63,88.32,47.27,28.58,20.38 ; \mathrm{IR}\left(\mathrm{CHCl}_{3}\right)$ 3313, $1679(\mathrm{C}=\mathrm{O}) \mathrm{cm}^{-1}$; LRMS (EI, $\left.20 \mathrm{eV}\right) \mathrm{m} / z 575\left(\mathrm{M}^{+}\right)$; HRMS (EI, $20 \mathrm{eV}$ ) for $\mathrm{C}_{31} \mathrm{H}_{37} \mathrm{~N}_{5} \mathrm{O}_{6}$ 
$\left(\mathrm{M}^{+}\right)$: calcd 575.2744, found 575.2730.

\section{Determination of association constants by ${ }^{1} \mathrm{H}$ NMR titrations.}

The $\mathrm{CDCl}_{3}$ solution of $\mathbf{1}(2 \mathrm{mM})$ was titrated by the addition of concentrated $\mathrm{CDCl}_{3}$ solution of mandelates (in the form of their tetrabutylammonium salts). To account for dilution effects, these anion solutions also contained receptor $\mathbf{1}$ at its initial concentration. The data were fit to a 1:1 binding profile according to the method of Wilcox (Wilcox, C. S. in Frontiers in Supramolecular Organic Chemistry and Photochemistry; Schneider, H.-J., Durr, H., Eds.; VCH;

Weinheim, 1991) using changes in the regular amide NH resonances (K, association constant; D, $\left.\Delta \delta_{\max }\right)$
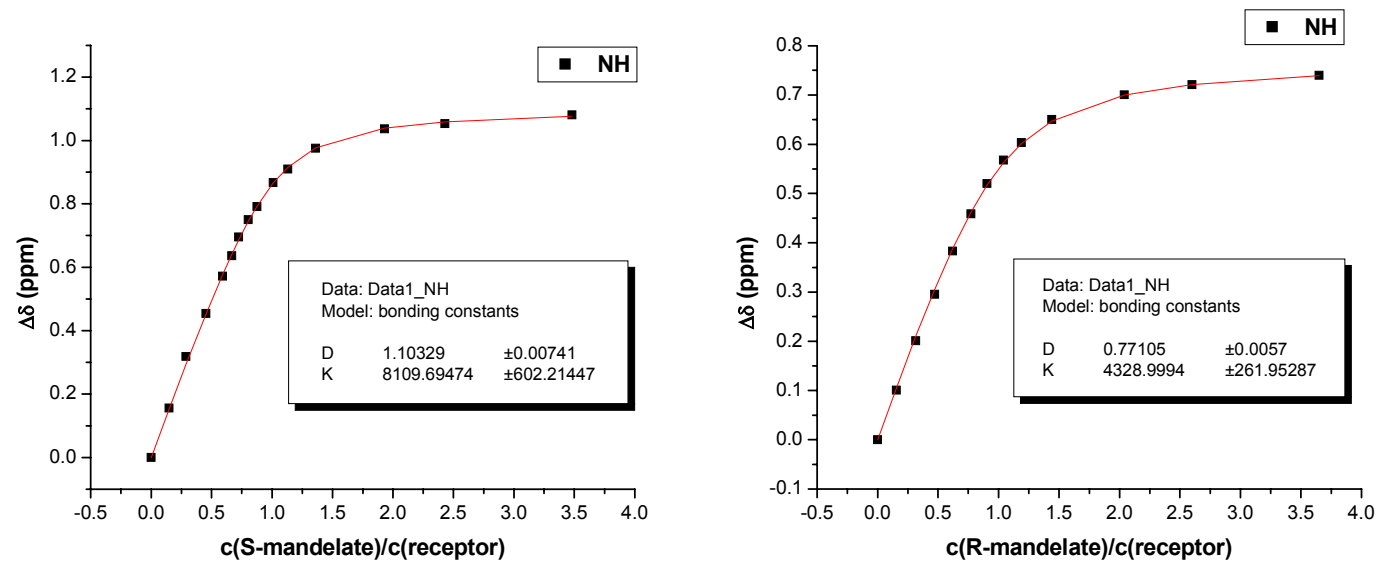


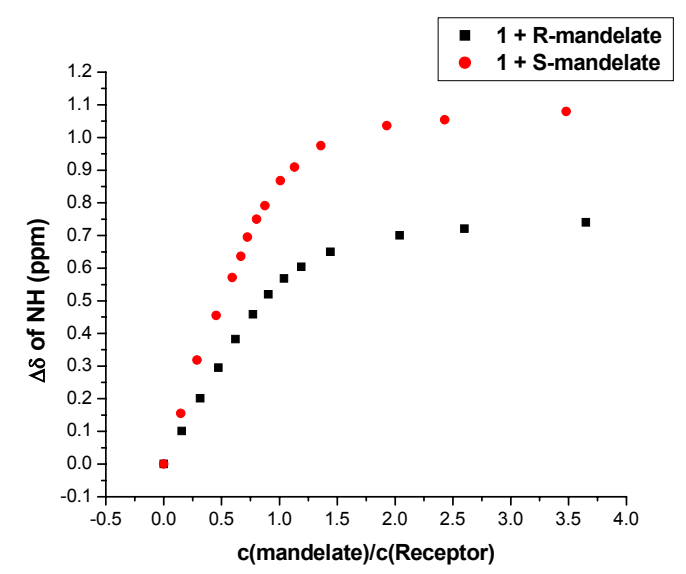

\section{Studies of the stoichiometry of the receptor-mandelate complex (Job plots) for 1.}

All recorded Job plots for 1 were found to exhibit maxima at $0.5 \pm 0.05$. This indicates that 1 forms a 1:1 complex with the mandelates in question. $(\mathrm{x}=[\mathbf{1}] /([\mathbf{1}]+[$ mandelate $])$; $\Delta \delta=$ variation of the chemical shift of the observed proton)

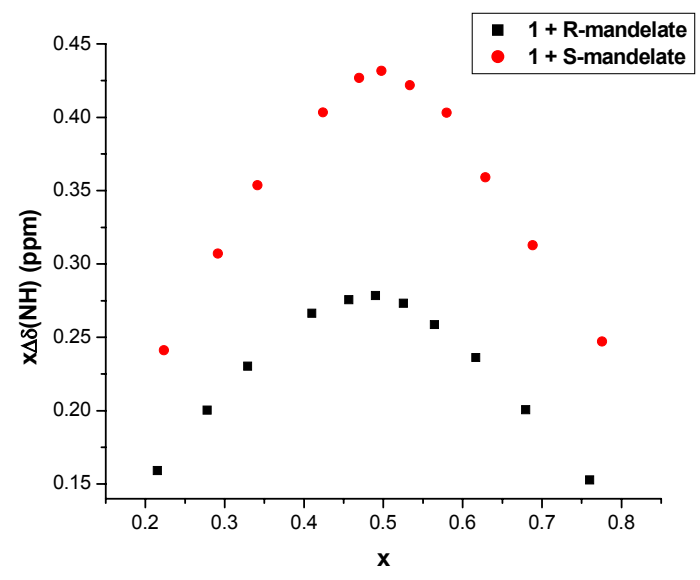

Determination of enantiomeric purity of mandelic acid.

To evaluate the accuracy of our determining method, we prepared six samples containing mandelic acid with $0,20,50,70,85$ and $90 \%$ ee, respectively (all samples were prepared by adding 1 equiv of tetrabutylammonium hydroxide and 1 equiv of receptor $\mathbf{1}$ in the solutions of 
mandelic acid $\left(5 \mathrm{mM}\right.$ in $\left.\mathrm{CDCl}_{3}\right)$ ), and determined their enantiomeric purities in the presence of receptor 1 by using ${ }^{1} \mathrm{H}$ NMR method. The results, which were calculated based on the integrations of the NMR signals, are shown in Figure S1. 
Figure S1. Determination of enantiomeric purity of mandelic acid

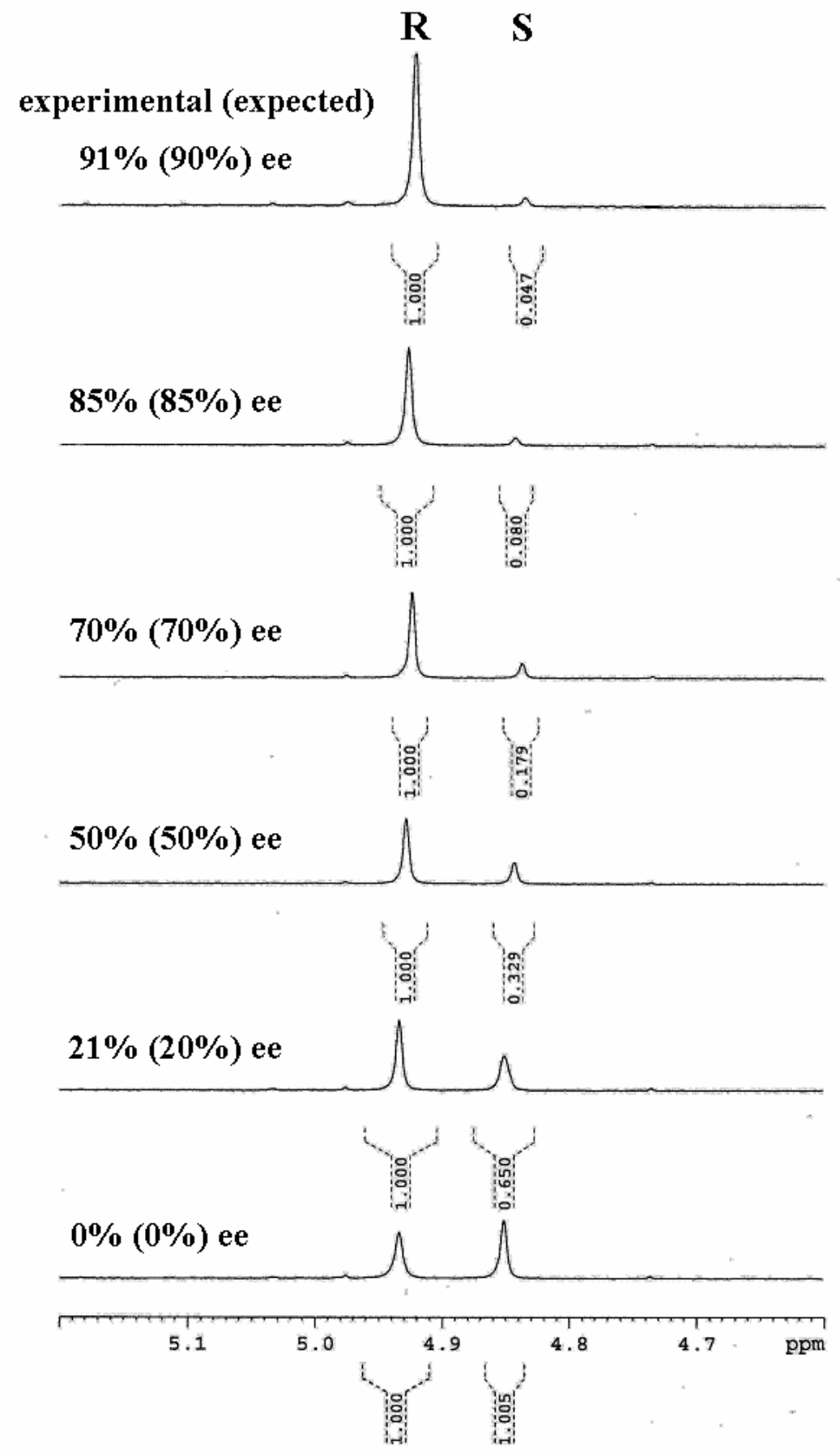

